Candidate in Economic Sciences, Associate Professor, Deputy Head of the Department of Informatics, Software Engineering and Economic Cybernetics, Kherson State University (Kherson, Ukraine);

Valeria Yatsenko,

Master Degree Student in International Economics, Taras Shevchenko National University of Kyiv (Kyiv, Ukraine)

\title{
WHAT CAN ECONOMIC EXPERIMENTS DISCOVER ABOUT EVOLUTIONARY EFFECTIVENESS OF SUPERMARKET STRATEGIES?
}

The paper analyses the variety of supermarkets' strategies (imitation and innovation) through economic experiment under which sales and prices will adapt to market demand. We compared strategies of supermarkets to demonstrate the advantages of supermarkets' strategy for imitators and innovators under different conditions. Our proposed algorithm for competitive supermarket model with fuzzy demand can be employed as a competitive strategy in a microeconomic system in which a wide range of different products/services are sold through supermarkets. We reveal the profitability of imitation strategy increases in the long-run period. With a small number of supermarkets (two or three), the innovative strategy of supermarkets turns out to be more beneficial. The number of supermarkets, number of steps and average price of products has a positive impact on the profit of supermarkets of both types.

Keywords: supermarket strategies, economic experiment, imitation strategy, innovation strategy, adaptive algorithm DOI: 10.21272/mmi.2018.1-11

General problem statement. The permanent expansion of consumers' demands, increasing requirements with respect to quality of attendance and service, comprehensive informatization along side with globalization processes stipulate radical transformations concerning not only the production of goods, but also production-sale system. Nowadays, the retail markets in countries all over the world show a tremendous potential and are growing fast. Over the past few years, retail has become one of the fastest growing sectors in the economy. S.S. Shenoy et al. noticed that organized retail is on an inflection pointand is expected to growat a robustspeed in the coming years [1]. To be successful in a competitive market, supermarkets have to adapt their strategies and tactics to the prevailing circumstances in the market environment. Determination of the most successful strategies for companies takes place through a series of experiments by means of evolutionary algorithms [2;3]. Companies undergo radical changes in the implementation of new strategies and technologies to respond to the challenges of the market environment, so they require such information systems that would ensure efficient and responsive order management to elim inate surplus goods in warehouses [4].

Responsive order is interpreted as market knowledge extracted through corporate websites and mobile apps to use the profit opportunities in volatile markets. Supermarket strategies include development of interconnected information network embracing suppliers, producers, distributors and buyers (fig. 1). For instance, W. E. Waterlander et al. have developed an innovative explorative tool to investigate the effects of retail price interventions in a virtual-reality setting with a huge potential to assist in gaining insightinto food purchasing behaviour: the virtual supermarket [5]. Strategies of supermarkets concern the effective use of not only marketpower, butalso its potential [6]. These strategies include the achievement of common interest (co-opetition), where one result is highly more profitable for supermarkets than another. For supermarkets, it can refer to the amount to orders to the same supplier.

Analysis of studies and publications. Numerous surveys on supermarkets and their market strategies have been made. R. Nelson etal. [10] and W. Cristaller [2] devoted their research articles to the analysis of supermarkets functioning. Also, many surveys were aimed at studying the strategies of supermarket behaviour. For instance, K. Ellis [1] analysed competitor-centric retail strategy, while B. Nair [1] described customer-centric retail strategy. S.S. Shenoy et al. [1], V.A. Zeithaml, Danaher, L.L. Berry [1], 
concentrated on high-quality client servicing. The aspects of supermarkets functioning in conditions of increasing competition were analysed by C. Marcon and N. Moinet[18], D.O. Lima etal. [21], V.B. Kumar [1], J. Vieira [23], A. Centenaro etal. [20] and C.G. Laimer [16], A. Balestrin [19] and T. S. Tomar [25] and others. The features and role of the assortment as one of the key parameters of the supermarket development strategy were investigated by J.R. Nevin [10] and M.J. Houston, J.D. Fisher, A.M. Yezeiy and H. Liu [1].

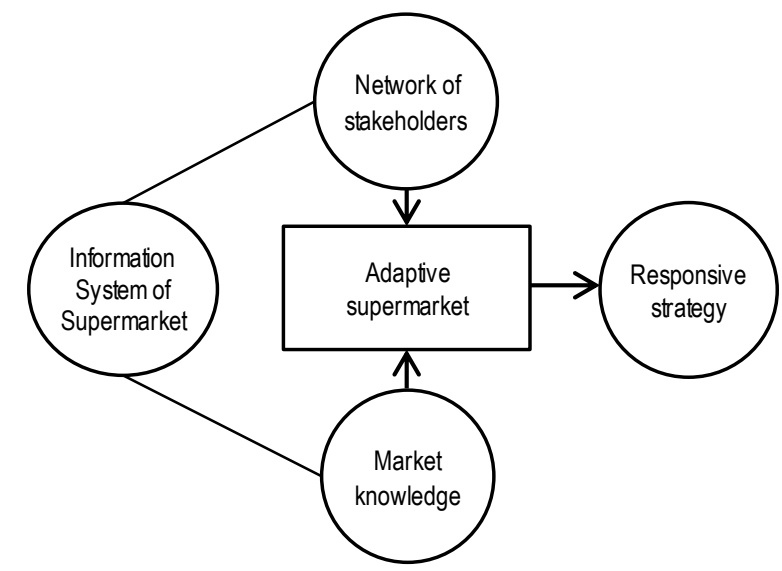

Figure 1 - Forming of responsive strategy of supermarket (developed by authors)

Unsolved aspects of the problem. Nevertheless, it was surprising to find limited academic research on econometric modelling of optimal supermarket strategies in product portfolio policy under rising market competition using experimental modelling [7].

The paper goal is analysis of supermarkets' strategies on the profits of innovator and imitator supermarkets through economic experiment.

\section{Results.}

1. Theories of activity of supermarkets as market agents

The majority of research workers give the prerogative of investigations to shopping centre. But similar logic and conclusions drawn after conducted investigations can also be converted into analysis of supermarkets' activities as long as both forms of the retail-trade organization provide for accumulation of a large number of sellers engaged in realization of various products (fig. 2).

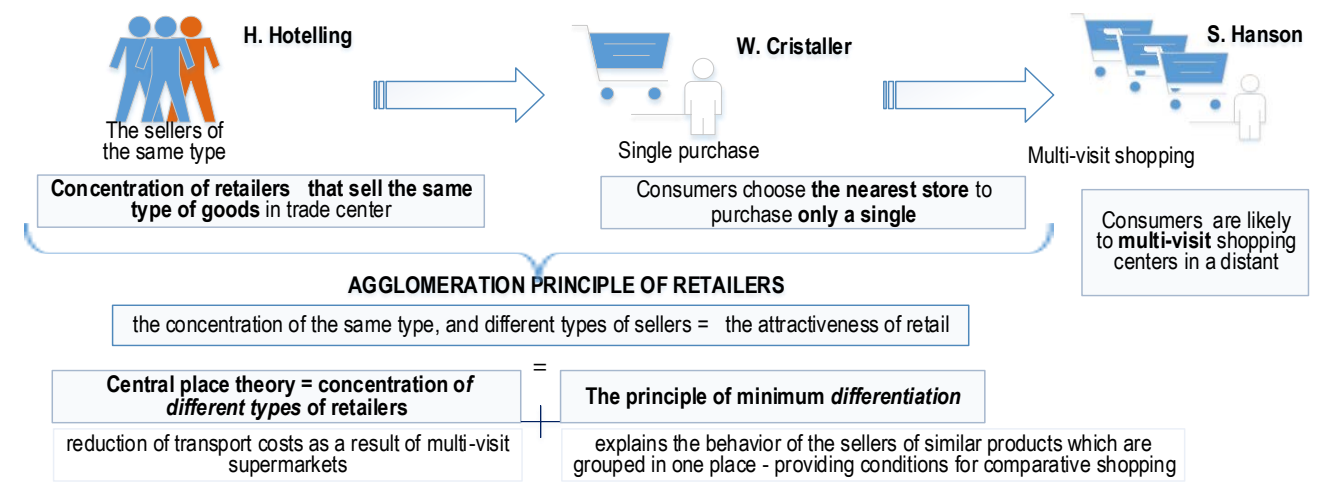

Figure 2 - Genesis of operation concepts of shopping centres (supermarkets) (developed by authors on the basis of $[2 ; 8 ; 9]$ ) 
В.М. Кобець, В.О. Яценко. Що можуть виявити економічні експерименти щодо еволюційної ефективності стратегій супермаркетів?

The key characteristic of the up-to-date chain of supermarkets is agglomeration of various sellers in space and in time on basis of use of conception connected with quick client servicing - («McDonaldization»), which facilitates and accelerates the process of purchasing on the part of consumers (fig. 3).

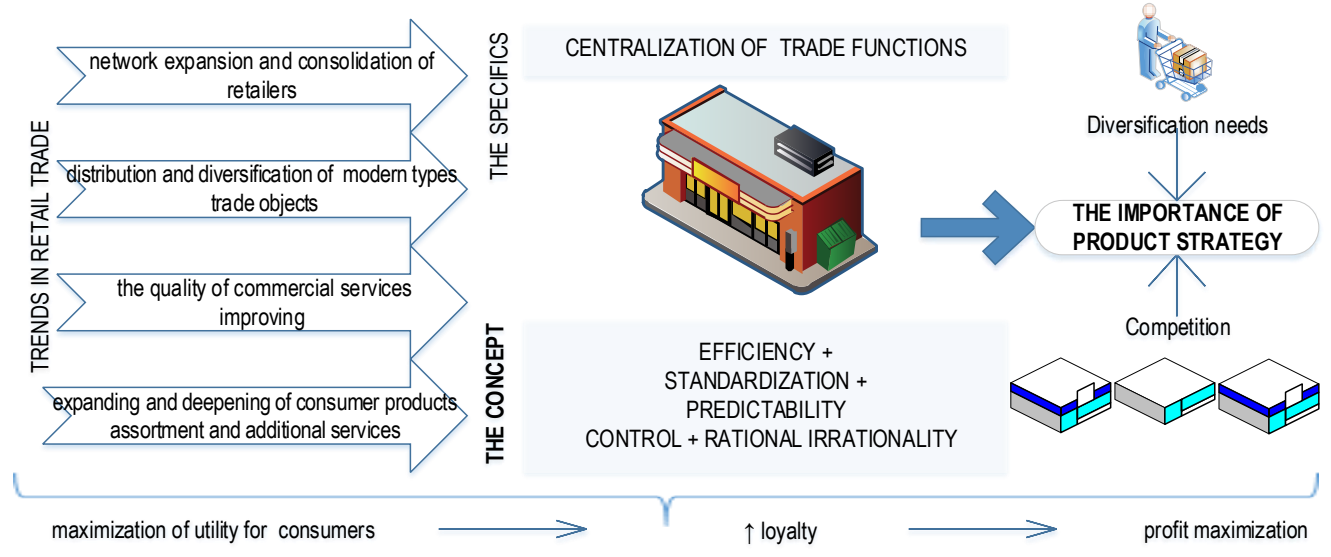

Figure 3 - Special features of operation of up-to-date chains of supermarkets

(developed by authors based on $[8,12]$ )

W. Cristaller, one of the firstresearchers who succeeded to formalize the model of spatial behaviour of retail traders, thought that consumers should choose the nearest shop for making only one purchase [2]. In our opinion, it is true, provided the consumers' tastes are homogeneous and the product range is relatively limited. However, availability of unique goods or rendering of specific services, in the online mode in particular, mitigate such competitive advantages of traditional supermarkets as: large areas, convenient geographical location, high advertising costs etc., providing high level of consumers' loyalty, which, according to our opinion, allows identifying the product-proposition strategy as the main component of strategy for development of any supermarket. Thus, for example, the investigation of structural factors of retail sales by J.R. Nevin and M.J. Houston proves that the assorment factor (diversity of retail goods for comparative purchases) forms more than half of the entire discovered variation in sales of trading centres [10].

Investigations conducted by R. Nelson et al., who analysed the principle of compatibility of retail traders, arouse interest. In accordance with the principle in question there is a correlation between profits earned by shops of different scale located close by a shopping centre [11].

On the ground of the specified logic, we think that availability of "anchor" or unique goods or services rendered by a supermarket increases the cost of concomitant purchases in direct proportion owing to synergy-effectaction. Because even in case of relatively higher level of supermarket prices consumers who buy unique goods, will also make concomitant purchases of the ordinary or impulsive demand provided that the supermarket uses the newest instruments of neuromarketing.

For example, the sale of weight peeled cereals is the special feature of the Polish chain of Ashan supermarkets, which differs from senvices of other supermarkets that propose pre-packed products solely, whereas the French chain Ashan makes Japanese sushi of their own production. The largest Ukrainian chain of supermarkets Silpo known for its wide line of goods is the only competitor proposing such service as smoking fish and seafood, which is rendered according to individual order and in customer's presence. Polish representatives of Tesco and Kaufland supermarkets chains propose their consumers unique assortment of strong beverages (first of all, beer) and sweets respectively, whose analogs are absent in the market. The chain of Georgian supermarkets named Nikora gives a wide choice of meats and meat products. 
These facts confirm the findings conducted by J.D. Fisher and A.M. Yezeiy according to which specific and unique goods widen the distance which consumers are ready to cover with a view of making purchases in a certain shopping centre or supermarket [8].

\section{Trends in retail development}

The retail sector, as the main channel for distributing products to the final consumer, faces two interconnected, but opposite trends. On the one hand, more and more retail sales are realized through large supermarketchains, which indicates a gradual monopolization of the market (fig. 4). On the other hand, the market is constantly facing increased competition between leading players in the market large supermarket chains.

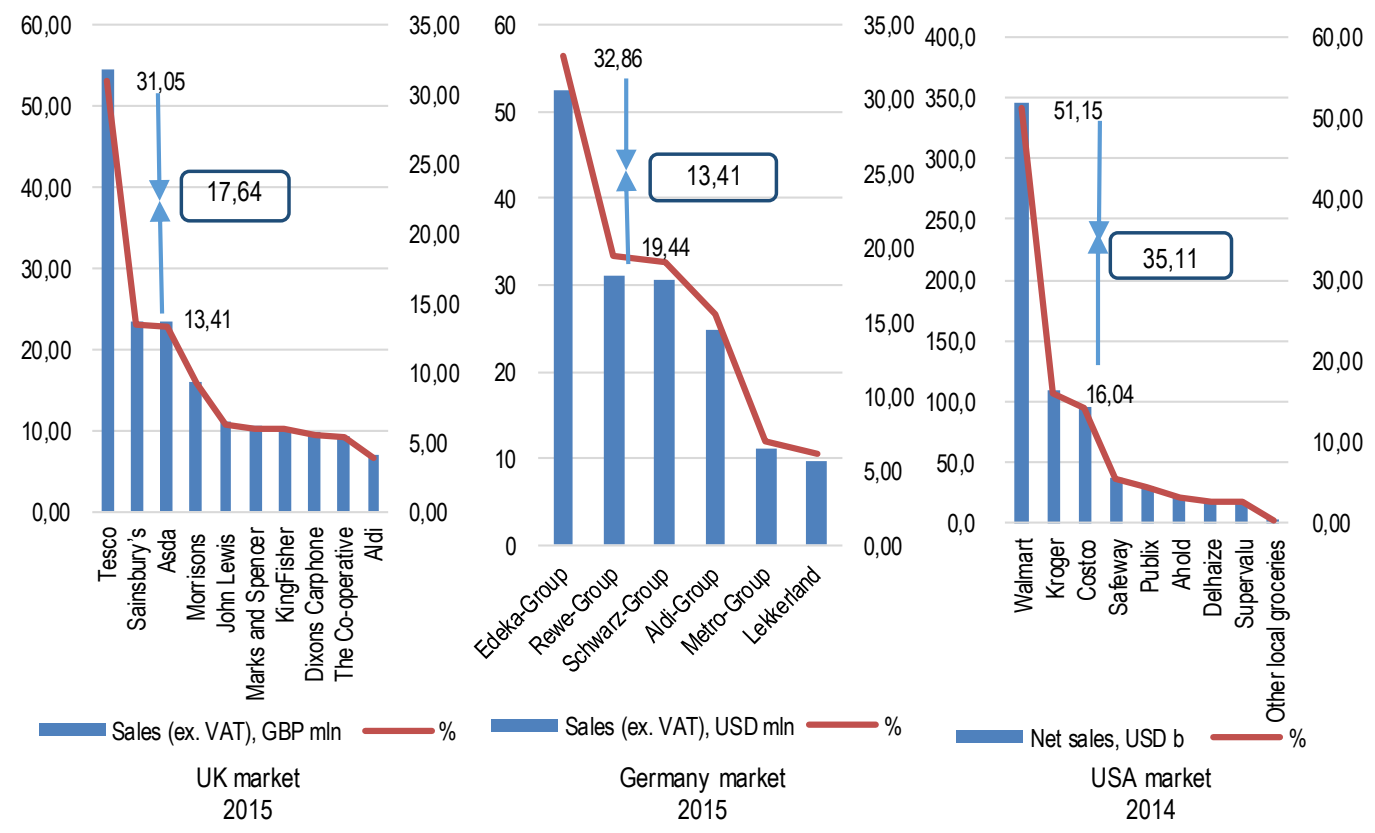

Figure 4-Distribution of the retail market between leading supermarket chains of Great Britain, Germany and the USA (given according to data [13; 14; 15])

It was envisaged that in highly competitive environment the main goal of every market agent is to defeat com petition and win newcustomers, which requires the search for the latest methods and tools to ensure competitive advantage in the market [1].

Due to high competition among supermarket chains in the retail sector, small and medium sized supermarkets, which are known as neighbourhood supermarkets, understand the necessity of establishing cooperative relationships with each other, through creation of cooperation networks [16; 17]. Such cooperation networks are inter-organizational relationships set up between com panies in the same segment in order to increase competitiveness [18; 19].

The arrangements with competitors or other supermarkets are connected with carrying out purchases, different promotions, human capital training and simpler information and knowledge exchange between the owners of supermarkets [20]. As a result, cooperative relationships with suppliers become the main factor of increasing competitiveness among supermarkets and company performance. These cooperative relationships or cooperation networks reflect a wide range of the alternatives for small 
В.М. Кобець, В.О. Яценко. Що можуть виявити економічні експерименти щодо еволюційної ефективності стратегій супермаркетів?

and medium-sized supermarkets in order to achieve competitive gains such as economies of scale, reducing logistics costs, improved product portfolio, better negotiating prices and terms with suppliers, marketing strategies implementation etc. [20;21]. In this case, we can sum up, escalating of market competition leads to gradual monopolization.

S. Kumar [22] opines that with intense competition among supermarket retailers, the markets are getting saturated and there arises a need to specificate competitive advantage among the all players. As a result, the growth of retail competition due to the appearance of new competitors, formats and technologies as well as critical changes in customer needs is stimulating retailers to pay more and more attention to attainment of competitive advantage [1]. S. Shenoy et al. think that intense competition, consolidation, and multinationalisation in the supermarket sector have also accelerated the spread of supermarket chains seeking to improve their competitive positioning [1].

In order to improve their own competitive advantages and achieve synergistic effect supermarkets chains unite their own efforts and cooperate. J. Vieira et al. [23] have studied that interpersonal integration between the agents and sharing costs and strategic integration significantly influence collaboration in supermarket retail chain.

A. Balestrin and J. Verschoore [24] highlight three attributes that are necessary for cooperative relationship to win competitive benefits; these are:

- alignment of interests and objectives,

- interaction,

- form of coordination activities management.

At the same time, retail trade, represented by large supermarket chains, is characterized by general tendencies of business development due to increasing role and pressure for innovation in modern business [25].

The analysis of the retail industry in the context of the network economy development and the formation of local networks is also important. For instance, the supermarket companies combined with networks had significantly higher level of cooperative relationship with suppliers. These networks positively impact on performance, and therefore demonstrate an advantage over the non-associated supermarkets [20].

\section{Assortment policy in the coordinates of supermarket development strategy}

One of the main reasons for updating the change in assortment policy is that opportunities for price differentiation have nearly vanished due to technology has been provision of greater information to the customer. As a result, with the wealth of information, which the customer has, it becomes imperative for the retailer to determine whether to provide superior customer services and better value for money or to broad the range of goods and services. Productassortment was also found by Sologard and Hansun [1] to be the single most important driver for choice between retail formats.

For instance, varieties ofa Japanese 7-Eleven brand are about 3000 items, and they are all popular goods. What is interesting, the headquarters recommend 80 new varieties monthly to its franchisee, so that the variety of merchandise business is often replaced to adapt to market changes so as to gives customers a sense of freshness [26].

Of interest is the investigation of $\mathrm{S}$. Lyengar and $\mathrm{M}$. Lepper who have proposed the choice overload hypothesis [27]. They distinguished the designs with psychologically manageable num bers of choices (limited-choice condition). In their jam promotion experiment, different numbers of jam jars were displayed in two separate tables in a supermarket, one consisting of six different types of jam and another - of twenty four types. They discovered that while the 24-jam table attracted more buyers than the 6-jam one, it did not successfully beef up their purchasing willingness. In their two additional experiments, this "more is less" result was also confirmed $[27 ; 28]$.

This experiment reflects the psychological nature of consumer choice [29]. Firstly, a person is characterized by the irrational nature of the purchases. Secondly, a person is not able to estimate the 
probability of everyday life and choose an optimal behaviour strategy due to limited cognitive capacity. Thirdly, human behaviour is limited because of tunnel vision and unwillingness to go beyond the frame of one's own experience. That is why consumers are willing to dwell on a variant with fewer alternatives (6 instead of 24 according to S. lyengar and M. Lepper's study), on condition that these alternatives are familiar and their quality is verified [27]. This confirms the earlier hypothesis about the importance of having "an anchor" product, rather than simply range extending.

In the opinion of S.-H. Chen and Y.-R. Du the use of exotic products in testing the choice overload hypothesisis justified [28]. As aresult they persuade that the assortment structure is an important control variable while testing the choice overload hypothesis [28]. For example, C. Mogilner, T. Rudnick, and $S$. lyengar [30] found that an increase in the number of alternatives decreased satisfaction only if the alternatives were not displayed in categories.

B. Scheibehenne, R. Greifeneder, and P. Todd found that the minimum number for the limitedchoice condition was 3 , whereas the maximum number for the extensive-choice condition was 300 [31], which is a slight diversity for supermarkets assortment. Using a random effect model, they found that the results were mixed, supporting neither the choice overload hypothesis ("more is less") nor its opposite ("more is better"). However, consumers who are experimentalists, relatively more prefer a wide range of choices, despite previous experience.

Therefore, in our opinion, the main element of the development strategy of any supermarket is to improve the product strategy, whose main goal is to form a line of unique products or services "anchors" that will increase consumer loyalty and stimulate the growth of sales due to synergistic effects.

Thus, it can be predicted that regardless of the target function of supermarkets (increase profit, expansion of the target segment, access to new markets, etc.), in conditions of increased competition between marketleaders, supermarket chains will face new challenges, which may be overcome, through cooperation or introducing innovations.

According to J. Schumpeter's theory, innovation comprises not only technical innovations, but also any new ways of resources combination, organizational changes, marketing implementations, etc [32]. Thatis why, in order to find an adequate response to currentmarket dem ands and diversification of the consumers requirements, supermarkets should provide the necessary conditions for the introduction of innovations, the dominant role among which will belong to assortment policy.

There is a need for new entrepreneurs to emerge and generate new economic activity which will eventually develop into larger business, thereby generating capital growth and employment opportunities; a substantial need also exists for entrepreneurship within the new knowedge-based, value-added business organizations of the global economic environment. In our opinion, this example can be not only neweconomic activity, but also the latest changes and innovations of existing activities, which will eventually develop into larger business in the form of creating and expanding a supermarket network.

\section{Variability of development strategies of modern supermarket chains}

As the competition in the countries retail sector has been increasing for years, the importance of developing an effective strategy appears to be increasing constantly [33]. In this day and age of increasing retail competition, though competitive advantage seems to be the only way out, choice of appropriate retail strategy has become a daunting task [1].

Many researchers have added strength to this argument by stating that retail companies need to be significantly more attractive to consumers than their competitors and should develop strategic positions in the market place [1]. A totality of all factors make itimperative for retailers to focus on the right kind of customer-centric strategies to attain superior performance and thereby achieve competitive advantage in the market place.

In this context, the optimal supermarket behaviour pattern will be to choose one of the three 
В.М. Кобець, В.О. Яценко. Що можуть виявити економічні експерименти щодо еволюційної ефективності стратегій супермаркетів?

alternative scenarios:

- imitation (selection of most profitable product range of supermarket),

- innovation (introduction of unique products, which have no competitors),

- adaptation (changes in prices and quantities of introduced assor tment of goods).

T.S. Tomar noticed that to stay in business, entrepreneurs must spread risk to innovate that is develop new products and services, at a high speed and on an efficient scale. More and more businesses choose for a model in which they specialize in one area. The consequence of this is that to innovate, these entrepreneurs increasingly rely on inputs from other entrepreneurs [25].

Examples of such inputs from other entrepreneurs in developing their own innovations (secondary innovations) may be the experience of introducing innovations by leading market leaders (primary innovations). Such secondary innovations, for example, may belong to changes in advertising, changes in the target segment, including changes in assortment policies on the model of the market leader. Thus, secondary innovation is a simulation of primary innovation and has a higher efficiency through the economy of time, financial and labour resources. The implementing process of successful innovations by the followers can be described as diffusion [32, p.] of the primary innovations in the market, while the adaptation is identified as a granulation process [28]. According to J. Schumpeter's classification, such innovations can be called additional, since their main task is not changing the economic complex or infrastructure in general, but a gradual variance in assortment of goods that will increase the profitability of the supermarket [32].

However, the process of implementing innovation into supermarket strategies certainly presumes risk, and therefore leads to a bifurcation point that, according to the theory of catastrophes and bifurcation, is the key of successful development of any system because it checks system viability and requires a comprehensive modernization. At the same time we know that the aim of most models of microeconomics is to achieve equilibrium point(Edgeworth box), optimum (Pareto optimum) or stability (model of general economic equilibrium L. Walras) (1). T.S. Tomar confirms this assumption and notes that entrepreneurship professionals mustbe even more frugal and wise with their decisions as they seek to innovate foster and retain sustainability [25].

$$
\lim _{x \rightarrow \infty} f(x) \rightarrow \text { stability }
$$

where $f(x)$ - function of the economic agent's behaviour.

As a result, it can be assumed that the strategy of innovation is used by supermarkets in the short run period during marketentry, catching a new target segment, modernizing development policies during a crisis, and so on. Instead, in the long run period, top management of supermarkets aims to achieve stability, which is provided by a strategy of simulation or adaptation according to the successful experience of market leaders. Thus, in business practice, the goal of revolutionary innovation is to achieve evolutionary stability.

However, according to the principles of dialectics and catastrophe theory, the continued stability of the system leads to its destruction. For example, according to Pareto law, $20 \%$ of chaos provides $80 \%$ of success and development. In order to achieve a successful development in the long run period, any counterparty's activities should constantly face crises and disturbances, including the introduction of untapped innovations.

The probability of applying an alternative strategy (innovation, imitation or adaptation) reflects one of the sim plestand most famous models of evolutionary genetics - the Hardy-Weinberg model. According to this model, there is only one abstract feature that is determined by two parameters (alleles) - two alternative behaviour strategies [32] (2). 


$$
1=(A+a)^{2}=A^{2}+2 A a+a^{2}
$$

We suppose supermarket $X$ has three alternatives to create assortment policy, which consists of 100 items of goods. Supermarket top-management decides to use different types of strategies for a large number of goods. For example, the strategy of innovation for the new or exotic goods, the strategy of adaptation for basic necessities, the strategy of imitation - for the second necessity goods (Table 1). Parameters $A$ and a represent the percentage of the supermarket product range, which is formed by a dominant or recessive strategy.

As a result, according to formula (2), it is possible to determine the probability of using a certain type of strategy or their combination in the process of assortment policy development. This model allows us to demonstrate that the frequency of recessive gene technology (strategies) in the evolution process decreases, which leads to the death of the subject if it functions through recessionary technologies (strategies) [32].

\section{Table 1 - The probability of using alternative combinations of supermarket product strategies} based on the Hardy-Weinberg's model

\begin{tabular}{|c|l|c|c|c|}
\hline № & \multicolumn{1}{|c|}{ Model Parameters } & Alternative № 1 & Alternative № 2 & Alternative № 3 \\
\hline 1 & \multicolumn{1}{|c|}{2} & 3 & 4 & 5 \\
\hline 1 & The dominant strategy & Innovation & Imitation & Innovation \\
\hline 2 & The recessive strategy & Imitation & Adaptation & Adaptation \\
\hline 3 & $\begin{array}{l}\text { Allel A - percentage of the commodity nomenclature formed } \\
\text { according to the dominant strategy, \% }\end{array}$ & 50 & 90 \\
\hline 4 & $\begin{array}{l}\text { Allel a - percentage of the commodity nomenclature formed } \\
\text { according to the recession strategy, \% }\end{array}$ & 50 & \multirow{2}{*}{10} \\
\hline 5 & The probability of using a dominant strategy & $0,25\left(=0,5^{2}\right)$ & $0,9(=0,81)$ \\
\hline 6 & Probability of application of recessive strategy & $0,25\left(=0,5^{2}\right)$ & $0,1(=0,01)$ \\
\hline 7 & Probability of strategies combination & $0,5\left(=2^{*} 0,5^{*} 0,5\right)$ & $0,18\left(=2^{*} 0,1^{*} 0,9\right)$ \\
\hline
\end{tabular}

\section{Economic experiments for supermarket strategies}

In the Nelson and Winter research [11], the difference between an imitator and an innovator is that the imitator chooses a new product group for its business from an assortment of highest-profit competitors, and the innovator chooses $50 \%$ of their range from available new products of suppliers for all firms in the industry, and $50 \%$ are formed from the range of highest-profit competitors in the industry. Our goal is to check which supermarket strategies (imitation or innovation) are more profitable under the assumptions of Nelson and Winter using simulation experiments. At the beginning of the experiment, each supermarket has an initial number of product groups in its range. After sale period, each supermarket tries to adapt its range for increasing in profit through changing its sales quantity and prices in all its product groups. When adaptation in sales quantity and price for all product groups is exhausted and in subsequent periods does not increase profits, the supermarket will begin to introduce into its assorment a combination of new products for consumers and products of the highest profit competitor (if supermarketis an innovator), or only products of the highest profit rivals (if supermarket is an imitator). Each supermarket knows the demand for its products, the wholesale price of suppliers, so after each trading period it can calculate its profits and compare it with the average profit of other retailers.

Input parameters of inverse demand functions for each product $P_{i}=b_{i}-c_{i}{ }^{*} Q_{i}, i=1, \ldots, n$ and whole prices of products $v_{j}, j=1, \ldots, m$, are chosen randomly from intervals $b_{i} \in[100 ; 1000], c_{i} \in[0.01 ; 1], v_{j} \in$ [10;50], respectively, where $P_{i}$ is a price of good in a supermarket, $Q_{i}$ is a volume of sales of product $i$ by all supermarkets, $b_{i}$ is reserve (maximum price) in the market, $c_{i}$ is a marginal price change due to unit change in sales quantity. The inverse demand function is necessary to determine the product price, which is required to calculate the profit of a supermarket. In the case of a direct demand function, we 
В.М. Кобець, В.О. Яценко. Що можуть виявити економічні експерименти щодо еволюційної ефективності стратегій супермаркетів?

need additional transformation of the price as a function of quantity. The total cost of each supermarket $j$ is determined from the function $T C_{j}=\sum_{i} V_{j i}{ }^{*} q_{j i}$.

Then average cost $A C_{j}$ and average price $\bar{p}_{j}$ of supermarket $j$ throughout the range of goods equal respectively (index ai means product $i$ in the assortment of supermarket $j$ ):

$$
\begin{gathered}
A C_{j}=\frac{\sum_{i} T C_{j i}}{\sum_{i} q_{j i}}, j=1, \ldots, m \\
\overline{p_{j}}=\frac{p_{a 1} * q_{a 1}+\ldots+p_{a n} * q_{a n}}{q_{a 1}+\ldots+q_{a n}} .
\end{gathered}
$$

The marginal profit of each supermarket is determined by the formula $\bar{p}_{j}-A C_{j}$ and gross profit of the supermarket is $\pi_{j}=\left(\bar{p}_{j}-A C_{j}\right) * q_{j}$, where $q_{j}=\sum_{a=1}^{n} q_{a j}$ is total quantity sales of supermarket $j$.

If supermarkets are selling unique products, they know the demand for these products, and they can set a ratio of "price-quantity" under which they getmaximum profitfrom the sale. If supermarkets imitate competitors' products, they divide market equally and they do not know the demand for product, so there is a need to adapt their output under unknown demand and sales of the supermarket, imitating the range of competitor. To do this, enter the following assumption: buyers can quickly compare the same product range in competitors' supermarket using their web sites or mobile applications. If a supermarket charges lowest price then it will be the first to sell the product. If there is deficit of product in the supermarket with lowest price then remaining unsatisfied buyers will switch on the product of second supermarket with higher price. After each period a supermarket determ ines deficit or surplus for each product under its prices and sales. If a supermarket finds deficit of products, then next time with a certain step $h_{i}$ it increases the size of the order and the price of the product; in case of surplus of product, it reduces the size order of product and the price for it with determined step $h_{i}$. The sequence of supermarket's decisions is in fig. 5 .

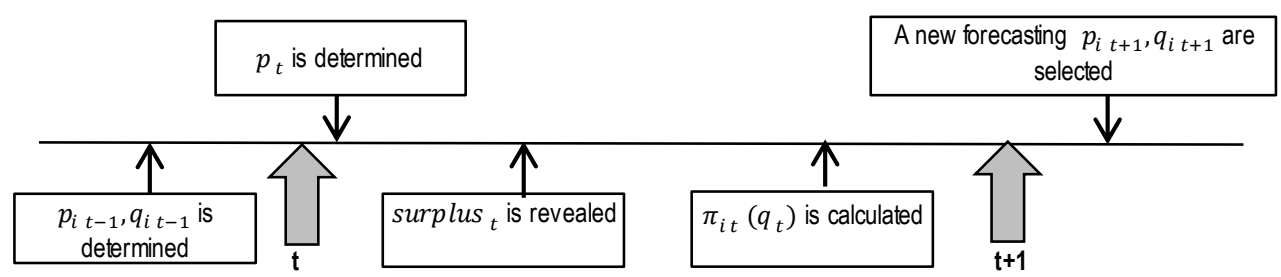

Figure 5 - Timeline of supermarket's decision making (developed by authors)

If the supermarket's profit for definite product is above the average in the industry, then next time with a certain step $h_{q}$ it increases the price of the product and with a determined step $h_{q}$ it increases the size of the order. If the profit of the supermarket for the products is lower than the average in the industry, then the supermarketreduces the price and size of the order of each product in the assortment with certain steps $h_{p}$ and $h_{q}$ respectively. After each adaptation period with the probability of $50 \%$ a supermarket-innovator introduces to its own assortment a new product from the initial range of 1000 new goods, which are absent in the market, and with the probability of $50 \%$ it selects a new product from the assortment of the most profitable competitor. A supermarket-imitator always chooses a new product randomly from the assortments of competitors who receive the most profits in the industry. The selection of supermarket 
products in its range is based on the consumer characteristics of the product, and not on its brand, whereas one of the dominant determinants of consumer behavior is inversion pricing, according to which products can cost expensive only in case when they provide unique characteristics or a new opportunity. That is why parameters $b_{i}$ and $c_{i}$ mean reserve (maximum) price in the market and a marginal price change due to unit change in sales quantity, but not product brand. We consider the type of product or product group which is available for order by all supermarkets in contrast of its own brands or own imports. The algorithm of decision making for adjusting the range of goods by each supermarket is presented in fig. 6 and Table 1.

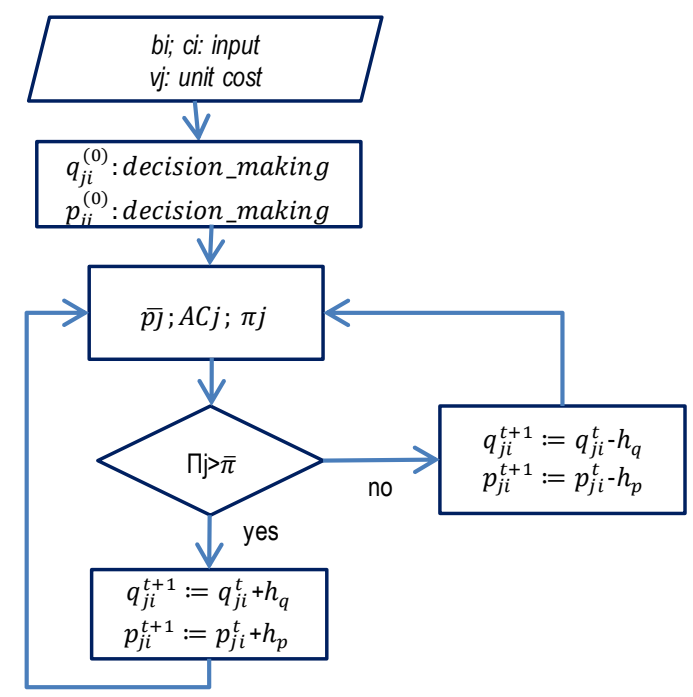

Figure 6 - Flow chart for supermarket's decision making (developed by authors)

Table 2 - The adaptive algorithm for supermarket strategy

\begin{tabular}{|l|l|}
\hline \multicolumn{3}{|c|}{ Algorithm 1 Adaptive algorithm for supermarket strategies } \\
\hline 1 & Initalization of $i$ supermarkets, $i=1,2$ \\
\hline 2 & Initalization of parameters $b$ and $c$ for demand function $P=b-c^{*} Q$ on product $k$ ( $P$ is maximal willingness to pay) \\
\hline 3 & Initialization of initial price $P_{j}^{k}$ and order $q_{j}^{k}$ on product $k$ for each supermarket \\
\hline 4 & Computation of average price $\bar{P}_{j}$, average cost $A C_{j}$ and profit $\pi$ for each supermarket \\
\hline 5 & If $\pi_{j}>\overline{\boldsymbol{\pi}}$ (profit of supermarket $j$ is more than the average profit of all supermarkets) \\
\hline 6 & then $q_{j i}^{t+1}:=q_{j i}^{t}+h_{q}, p_{j i}^{t+1}:=p_{j i}^{t}+h_{p}$ (adaptive procedure for deficit of product) \\
\hline 7 & else $q_{j i}^{t+1}:=q_{j i}^{t}-h_{q}, p_{j i}^{t+1}:=p_{j i}^{t}-h_{p}$ (adaptive procedure for surplus of product) \\
\hline 8 & $\begin{array}{l}\text { Comparative dynamics of average profits for supermarkets' strategies for innovators and imitators } \\
\bar{\pi}_{j}^{\text {innov } v s} \bar{\pi}_{k}^{\text {imit }}\end{array}$ \\
\hline
\end{tabular}

The supermarket profit indicator is first checked to change the sales quantity and price of the existing product groups in its range. If a supermarket reveals a deficit of goods, it will increase quantity of orders and product price in order to increase profit. If a supermarket finds out product surplus, it will reduce quantity of orders and product price in order to increase profit. After profit indicator stops increase, the supermarket will introduce new product group to its range, then again check the impact of changes in the quantity sales and prices of the new product group to its profit and so on. The algorithm is repeated until the change of supermarkets' profit becomes insignificant (less than predetermined $\varepsilon$ ), after this 
В.М. Кобець, В.О. Яценко. Що можуть виявити економічні експерименти щодо еволюційної ефективності стратегій супермаркетів?

supermarket stops changes in the assortment and final indicators are fixed.

The following formula is used to determine the required number of experiments to reveal the structure of the relationships between the profit of the supermarket and the explanatory variables [34]:

$$
N=(1.5 \div 2)\left(1+\sum_{i=1}^{m} L_{i}\right)
$$

where $m$ is number of explanatory variables, $L_{i}$ is the degree of approximation on factor $i, L_{i}=$ $F_{i}-1$, where $F_{i}$ is a number of variation levels of each independent variable. Application of the formula (5) using experiments allows us to obtain conclusions which are adequate to reality in $95 \%$ cases.

Using formula (5), from Table 4 for explanatory variables from the column Max we get $F_{1}=20$, $F_{2}=6 F_{3}=100,, F_{4}=499$. After substituting the values of $F_{i}$ into formula (5) we have: $\min N=$ $1.5\left(1+\sum_{i=1}^{m} L_{i}\right)=1.5 \cdot(1+(20-1)+(60-1)+(10-1)+(499-1))=879$ $\max N=2\left(1+\sum_{i=1}^{m} L_{i}\right)=2 \cdot(1+(20-1)+(60-1)+(10-1)+(499-1))=1172$. From this calculations we have the average number of experiments needed to obtain the results that are adequate to the reality should be $N=\frac{\min N+\max N}{2} \approx 1000$.

After applying of the adaptive algorithm demonstrated in fig. 6 and Table 2 to the supermarkets assortment, we obtain the results of the experiments $1,10,100,200, \ldots, 1000$ in Table 3.

Table 3 - Experimental results of supermarket-innovator strategy

\begin{tabular}{|c|c|c|c|c|c|}
\hline $\begin{array}{c}\text { Experiment } \\
\text { number }\end{array}$ & $\begin{array}{c}\text { Average profit of } \\
\text { innovators } \boldsymbol{y}\end{array}$ & $\begin{array}{c}\text { Number of } \\
\text { supermarkets } \mathbf{x}_{\mathbf{1}}\end{array}$ & $\begin{array}{c}\text { Number of } \\
\text { steps } \mathbf{x}_{2}\end{array}$ & $\begin{array}{c}\text { nitial average number } \\
\text { of products } \mathbf{x}_{3}\end{array}$ & $\begin{array}{c}\text { Average price of } \\
\text { products } \mathbf{x}_{4}\end{array}$ \\
\hline 1 & 139547 & 16 & 27 & 7 & 286 \\
\hline 10 & 112798 & 14 & 33 & 3 & 203 \\
\hline 100 & 39353 & 5 & 16 & 5 & 48 \\
\hline 200 & 46402 & 18 & 38 & 5 & 9 \\
\hline 300 & 57435 & 2 & 19 & 3 & 396 \\
\hline 400 & 103424 & 3 & 53 & 8 & 263 \\
\hline 500 & 222968 & 14 & 54 & 3 & 289 \\
\hline 600 & 344486 & 18 & 33 & 9 & 302 \\
\hline 700 & 167187 & 5 & 45 & 1 & 97 \\
\hline 800 & 103130 & 12 & 51 & 6 & 379 \\
\hline 900 & 300210 & 8 & 8 & 9 & 5 \\
\hline 1000 & 15652 & 16 & 31 & 6 & 54 \\
\hline Average & 168141,69 & 11 & & & 251 \\
\hline
\end{tabular}

Table 4 shows the main statistical indicators: the number of supermarkets in the city varies from 2 to 20; the number of periods during which the supermarket adapts the set of prices and quantities of products, changes from 1 to 60 periods ( 1 period = 1 week); the initial quantity of product groups (which may include a wide range of homogeneous goods classified according to the Harmonized Commodity Description and Coding System) in the supermarkets assortment ranges from 1 to 10 . For instance, it was found that an average Dutch supermarket offers about 7,000 different food products. Since this number contains approximately 200 different types of cheese and 250 varieties of wine, it was decided that a representative product selection should be made using the 38 different food categories of the supermarket assortment. These categories com prise, for example, potatoes, vegetables, poultry, fish, soft drinks, confectionary, and bread [35]. However, if we continue to generalize the commodity positions, the whole range of the standard supermarket assortment can be classified into 10 product groups. The average price of products in supermarkets is in the range from $\$ 1$ to $\$ 499$. The profit of 
supermarket innovators after adaptation periods varies from minimum of $\$ 1025$ to maximum of $\$ 4891533$.

In order to evaluate the effectiveness of innovators and imitators strategies, we conducted 1,000 experiments in which we estimated dependence of the innovators' and imitators' profits (fig. 7) on the number of supermarkets $\left(x_{1}\right)$, the number of steps for adjusting the range of goods to the demand of consumers $\left(x_{2}\right)$, and the average initial number of products in the assortment of supermarkets $\left(x_{3}\right)$ and the average price of goods in supermarkets $\left(x_{4}\right)$.

Table 4 - Statistical indicators of supermarket activities

\begin{tabular}{|c|c|c|c|c|c|}
\hline variable & Obs & Mean & Std. Dev. & Min & Max \\
\hline $\mathrm{y}$ & 1000 & 164821.6 & 235643 & 1025 & 4891533 \\
\hline $\mathrm{x} 1$ & 1000 & 11.022 & 5.50689 & 2 & 20 \\
\hline $\mathrm{x} 2$ & 1000 & 30.912 & 17.23518 & 1 & 60 \\
\hline $\mathrm{x} 3$ & 1000 & 5.698 & 2.884982 & 1 & 10 \\
\hline
\end{tabular}

For clarity in fig. 7 is shown the representative profits' dynamics of 4 supermarkets, two of which follow the strategies of the imitator, while other two follow strategies of innovators. Fig. 7 shows that the profits of the imitators have about average value, while the profit of the innovator can be both significantly higher and significantly below the average profit in the industry.

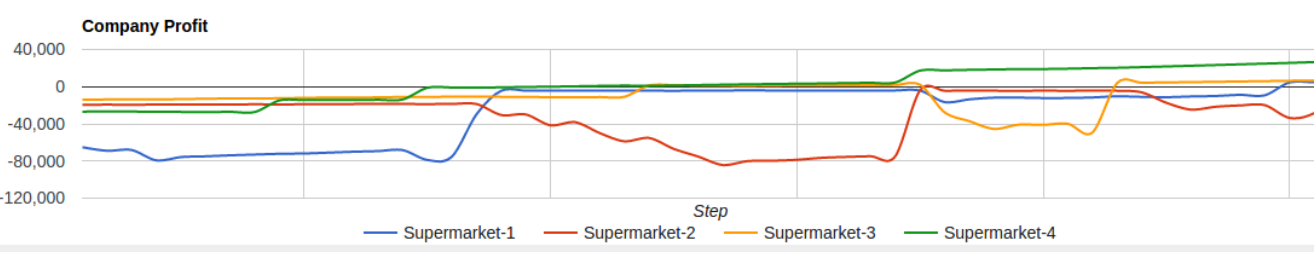

Figure 7-Dynamics of supermarkets profit during the process of adjusting the assortment to demand (supermarkets 1 and 3 are imitators; supermarkets 2 and 4 are innovators) (author's calculations)

Based on experimental data, we estimate the parameters of multiple regression in the following form:

$$
y=b_{0}+b_{1} * x_{1}+b_{2} * x_{2}+b_{3} * x_{3}+b_{4} * x_{4}+u
$$

The obtained results (fig. 8) show low statistical significance of the parameters of multiple regression and its inadequacy in reality, because the determination coefficient $\mathrm{R}^{2}+28.37 \%$.

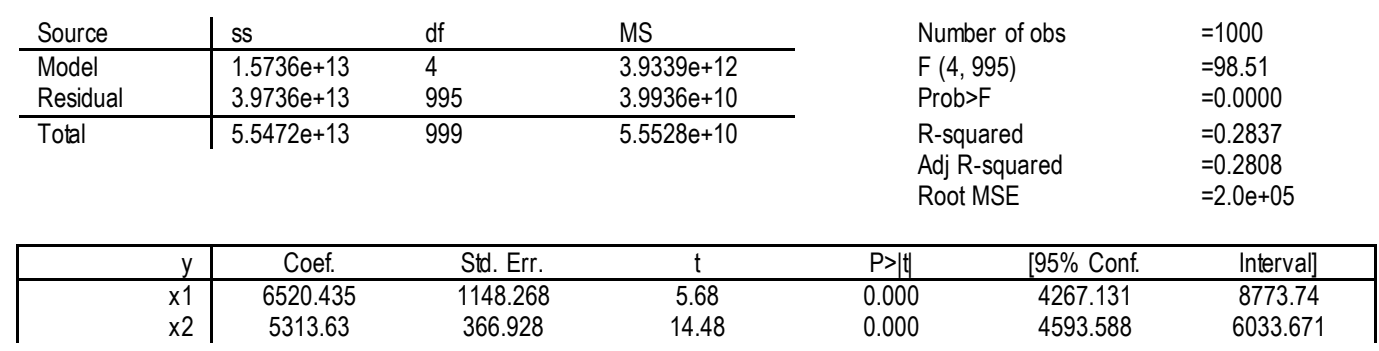


В.М. Кобець, В.О. Яценко. Що можуть виявити економічні експерименти щодо еволюційної ефективності стратегій супермаркетів?

\begin{tabular}{|r|cccccc|}
\hline x3 & -12060.57 & 2192.7 & -5.50 & 0.000 & -16363.42 & -7757.726 \\
x4 & 473.679 & 43.43464 & 10.91 & 0.000 & 388.445 & 558.913 \\
cons & -121668.6 & 24319.31 & -5.00 & 0.000 & -169391.6 & -73945.55 \\
\hline
\end{tabular}

Figure 8 - Regression analysis for multiple linear model (5) (author's calculations)

After taking the logarithm of the dependent and explanatory variables from equation (6) and the determination of the parameters in the statistical package Stata we received the results shown in fig. 9.

\begin{tabular}{|c|c|c|c|c|c|}
\hline Source & ss & $d f$ & MS & Number of obs & $=1000$ \\
\hline $\begin{array}{l}\text { Model } \\
\text { Residual }\end{array}$ & $\begin{array}{l}778.069086 \\
225.301668\end{array}$ & $\begin{array}{l}4 \\
995\end{array}$ & $\begin{array}{l}194.517272 \\
.226433837\end{array}$ & $\begin{array}{l}F(4,995) \\
\text { Prob }>F\end{array}$ & $\begin{array}{l}=859.05 \\
=0.0000\end{array}$ \\
\hline Total & 1003.37075 & 999 & 1.00437513 & $\begin{array}{l}\text { R-squared } \\
\text { Adj R-squared } \\
\text { Root MSE }\end{array}$ & $\begin{array}{l}=0.7755 \\
=0.7746 \\
=.47585\end{array}$ \\
\hline
\end{tabular}

\begin{tabular}{|r|cccccc|}
\hline $\mathrm{ly}$ & Coef. & Std. Err. & $\mathrm{t}$ & $\mathrm{P}>|\mathrm{t}|$ & {$[95 \%$ Conf. } & Interval] \\
\hline $\mathrm{l} 1$ & .1944966 & .0233164 & 8.34 & 0.000 & .1487417 & .2402515 \\
$\mathrm{lx3}$ & -.1152585 & .0220418 & -5.23 & 0.000 & -.1585123 & -.0720048 \\
$\mathrm{l} 2$ & .7891762 & .0178007 & 44.33 & 0.000 & .754245 & .8241074 \\
Ix4 & .5693506 & .0149933 & 37.97 & 0.000 & .5399285 & .5987728 \\
cons & 5.837458 & .1144444 & 51.01 & 0.000 & 5.612878 & 6.062038 \\
\hline
\end{tabular}

Figure 9 - Regression analysis for multiple log-linear model (6) (author's calculations)

In fig. 9 we received parameter values, confidence intervals for these parameters and their statistical significance. For innovator supermarkets introducing new products, which their competitors don't have, we obtain the following result:

$$
\begin{gathered}
\ln y=5.84+0.19 * \ln x_{1}+0.79 * \ln x_{2}-0.12 * \ln x_{3}+0.57 * \ln x_{4} \\
R^{2}=77.5 \%
\end{gathered}
$$

All regression parameters (7) are statistically significant. After $1 \%$ increasing in the number of supermarkets, the profit of the innovators increases by $0.19 \% ; 1 \%$ increasing in adjustment steps causes $0.79 \%$ growth of the innovator supermarket's profit; $1 \%$ increasing in the average price of goods leads to innovator's profitincreasing by $0.57 \%$. At the same time, $1 \%$ expansion of the initial assortment reduces the profit of the supermarket by $0.12 \%$.

For supermarkets imitating the assortment of their competitors (both im itators and innovators), which brings the greatest profit, the following dependence is obtained:

$$
\begin{gathered}
\ln y=6.07+0.2 * \ln x_{1}+0.79 * \ln x_{2}-0.13 * \ln x_{3}+0.53 * \ln x_{4} \\
R^{2}=75.2 \%
\end{gathered}
$$

All regression parameters (8) are also statistically significant. After $1 \%$ increasing in the number of supermarkets, the profit of the imitators increases by $0.2 \% ; 1 \%$ increasing in adjustment steps causes growth by $0.79 \%$ of the imitator supermarket's profit; $1 \%$ increasing in the average price of goods in supermarkets leads to profit increasing of imitators by $0.53 \%$. At the same time, $1 \%$ expansion of the initial assortment reduces the profit of the supermarket by $0.13 \%$.

In the long-run period, the profitability of imitation strategy increases. This is because the imitation strategy replicates the most favorable agreements for the range of goods in other supermarkets, while the innovative strategy carries risks of obtaining low profits from the new product (experience good) in 
the assortment. So imitator supermarkets get higher profits than innovator supermarkets $(65.3 \%$ of imitators versus $34.7 \%$ of innovators) (fig. 10 ).

With a small number of supermarkets (two or three), the innovative strategy turned out to be more beneficial. This is because the imitators make a sample for copying the most profitable products from assorments of all the supermarkets-competitors (not only innovators, but also other imitators). Because the sam pling of goods is smaller with a small number of supermarkets, the imitators cannot fully realize their potential, and since the number of imitators is insignificant, the most advantageous transaction does not spread so quickly. So, in this case, the average profit of innovators $(\$ 126587,2)$ is above the average profit of the imitators $(\$ 126513,6)$.

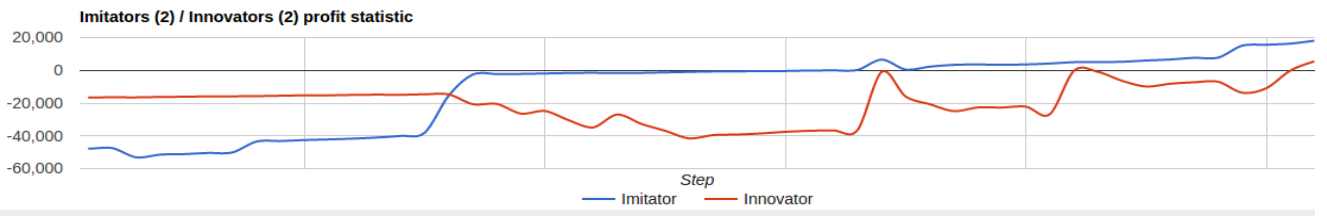

Figure 10-Comparative dynamics of profits for innovator and imitator supermarkets (author's calculations)

Conclusions and directions of further research. We compared strategies of supermarkets to demonstrate the advantages of supermarkets' strategy for imitators and innovators under different conditions. Our proposed algorithm for competitive supermarket model with fuzzy demand was employed as a competitive strategy in a microeconomic system in which a wide range of different products/services is sold through supermarkets. In the long-run period, the profitability of imitation strategy increases. So imitator supermarkets get higher profits than innovator supermarkets $(65.3 \%$ of imitators versus $34.7 \%$ of innovators). With a small number of supermarkets (two or three), the innovative strategy turned out to be more beneficial. In this case, the average profit of innovators is above the average profit of the imitators.

Using software package we obtained that the profit of supermarkets will increase if the number of supermarkets, number of steps for adaptation of its range and average price of demanded products increase. At the same time, the profit of supermarkets will decrease if initial average number of product groups increases.

1. Shenoy S.S. Service Quality: The Cornerstone of Customer-Centric Retail Strategy for Supermarket Retailers in India [Electronic resource] / S.S. Shenoy, A.H. Sequeira, K. Devaraj // International Journal of Marketing \& Business Communication. 2012. - P. 11-17. - Mode of access: htps://ssrn.com/abstract=2025463.

2. Cristaller W. Centeral Places in Southern Germany, englewood Cliffs / W. Cristaller ; trans. by C. W. Baskin. - NJ: Prentice-Hall. -1996.

3. Кобець В.М. Тарифна політ ика транспортної компанії-монополіста при доставці продукції т виробників на n ринків / В.М. Кобець // Актуальні проблеми економіки. - 2009. - № 5. - С. 263-271.

4. Matos N. Determining Successful Negotiation Strategies: An Evolutionary Approach / N. Matos, C. Sierra, N.R. Jennings // Proc. Third Intl Conf. Mult-Agent Systems. - 1998. - P. 182-189.

5. Waterlander W.E. Energy density, energy costs and income-how are they related? / W.E. Waterlander, W.E. de Haas, I. van Amstel, A.J. Schuit, J.W. Twisk, M. Visser, J.C. Seidell, I.H. Steenhuis // Public health nutrition. - 2010. - N 13(10). - P. 1599-1608. DOI: $10.1017 /$ S1368980009992989.

6. Gunasekaran A. Responsive supply chain: Acompetitive strategy in a networked economy / A. Gunasekaran, Keehung Lai, T.C. Edwin Cheng // Omega. - 2008. - Vol. 36, Issue 4. - P. 549-564.

7. Kobets V. Dynamic model of double electronic Vickrey auction [Electronic resource] / V. Kobets, V. Yatsenko, M. Poltoratskiy // Proc. 11-th Int. Conf. ICTERI 2015, Kherson, Lviv, May 14-16 ; Ermolayev, V. (eds.). - 2015,- P.236-251. Mode of 
В.М. Кобець, В.О. Яценко. Що можуть виявити економічні експерименти щодо еволюційної ефективності стратегій супермаркетів?

access: CEUR-WS.org/Vol-1356/ICTERI-2015-CEUR-WS-Volume.pdf.

8. Чернікова Г. Еволюція теорії торговельних центрів [Електронний ресурс] / Г. Чернікова // Товари і ринки. - 2010. № 2. - С. 27-38. - Режим доступу: http://nbuv.gov.ua/UJRN/tovary_2010_2_6.

9. Hanson S. Spatial Diversification and Multipurpose Travel: Implications for Choice Teory / S. Hanson // Geographical Analysis. - 1980. - N 12. - P. 245-257.

10. Nevin J.R. Imaje as a Component of Attraction to Intraurban Shopping Areas / J.R. Nevin, M.J. Houston // Journal of Retailing. - N 56. - 1980. - P. 77-93.

11. Nelson R.R. An Evolutionary Theory of Economic Change / R.R. Nelson, S.G. Winter // Cambridge, MA: The. Belknap Press of Harvard University Press. - 1982. $-430 \mathrm{pp}$.

12. Ritzer G. The "McDonaldization" of Society / G. Ritzer // The Journal of American Culture. - 2004. - N 6(1). - P. 100107 .

13. 8 largest grocers in the U.S [Electronic resource]. - Mode of access: http://www.pennlive.com/midstate/index.ssf/2015 06/8_largest_grocers_in_the_us.html.

14. Top 10 UK Retailers by Sales in 2015/2016 [Electronic resource]. - Mode of access: http://retaileconomics.co.uk/top10retailers.asp.

15. USDA Foreign Agriculyural Service. Global Agricultural Information Network [Electronic resource]. - Mode of access: https://gain.fas.usda.gov/Recent\% 20GAIN\%20Publications/Retail\%20Foods_Berlin_Germany_11-22-2016.pdf.

16. Laimer C. G. Relações de cooperação na perspectiva da visão baseada em recursos / C. G. Laimer, V. R. Laimer // Revista de Administração da Unimep. - 2009. - N 7(3). - P. 93-110.

17. Gaspar M.A. Estrategia de atuacao em rede de negocios: Estudo de caso no pequeno varejo de alimentos / M.A.

Gaspar, F. Borgato, I.C. Lima // Revista da Micro e Pequena Empresa. - 2013. - N 7(1). - P. 3-16

18. Marcon C. Estratégia-rede: Ensaio de estratégia / C. Marcon, N. Moinet - Caxias do Sul: Educs. - 2001.

19. Balestrin A. A dimensão estratégica das redes horizontais de PMEs: Teorizações e evidências / A. Balestrin, L.M. Vargas // Revista de Administração Contemporânea. - 2004. - N 8(1). - P. 203-228.

20. Centenaro A. Cooperative relationships and competitiveness in supermarket sector / A. Centenaro, Claudinior G. Laimer // Review of Business Management, São Paulo. - 2017. -Vol. 19, No. 63. - P. 65-81

21. Lima D.O. Redes de cooperacao no varejo alimentar de vizinhanca: Percepcoes dos associados / D.O. Lima, F.S. Fo Maia, R. L. Sproesser, F. Moraes, R. Moraes // Gestro \& Produ3ro. - 2006. - N 13(2). - P. 311-324

22. Ganguli S. Drivers of customer satisfaction and loyalty in India retail supermarkets: An exploratory study / S. Ganguli, V.B. Kumar // ICFAI Business Review June. - 2008. - P. 61-66.

23. Vieira J. Collaboration intensity in the Brazilian supermarket retail chain / J. Vieira, H. Yoshizaki, L. Ho // Supply Chain Management - 2009 - N 14(1) - P. 11-21.

24. Balestrin A. Redes de cooperaзго empresarial: Estrath̆gias de gestro na nova economia (2a ed.) / A. Balestrin, J. Verschoore // Porto Alegre: Bookman. - 2016

25. Tomar T.S. Entrepreneurship Development and Innovation Management: Key Connections / S.T. Tomar // 4th International Conference on Innovation and Entrepreneurship. In K.A. Grant, S. Wise (Eds.). - 2016. - P. 263-271

26. Huang T. The Distribution Strategies of Convenience Stores Chain in China from Japan 7-11 / Ting Huang, Liu Chunxiong // Web of Conferences 100. - 2017. - P. 1-5.

27. Lyengar S. When choice is demotivating: Can one desire too much of a good thing? / S. Lyengar, M. Lepper // Journal of Personality and Social Psychology. - 2000. - N 79(6). - P. 995-1006.

28. Chen Shu-Heng. Granularity in Economic Decision Making: An Interdisciplinary Review / Shu-Heng Chen, Ye-Rong Du // Granular computing and decision-making: interactive and iterative approaches; W. Pedrycz, S. Chen (eds.). - 2015. - P. 47-71. DOI: 10.1007/978-3-319-16829-6 3.

29. Kobets V. Nonlinear Dynamic model of a microeconomic system with different reciprocity and expectations types of firms: Stability and bifurcations [Electronic resource] / V. Kobets, A. Weissblut // CEUR Workshop Proceedings. - 2016. - vol. 1614. - P. 502-517. - Mode of access: CEUR-WS.org/Vol-1614/ICTERI-2016-CEUR-WSVolume.pdf.

30. Mogilner $\mathrm{C}$. The mere categorization effect How the presence of categories increases choosers' perceptions of assortment variety and outcome satisfaction / C. Mogilner, T. Rudnick, S. lyengar // Journal of Consumer Research. -2008 . $-\mathrm{N}$ $35(2)$

31. B. Scheibehenne Can there ever be too many options? A metaanalytic review of choice overload / B. Scheibehenne, R. Greifeneder, P. Todd // Journal of Consumer Research. - 2010. - N 37(3). - P. 409-425.

32. Кузьмін О.Є. Досягнення і проблеми еволюційної економіки : монограффія / О.Є. Кузьмін, Ю.І. Сидоров, В.В. Козик; МОНМС України, Нац. ун-т "Львів. політехніка". - Львів, 2011. - 251 с.

33. Harris L. Competitive advantage in UK food retailing sector: past, present and future / L. Harris, E. Ogbonna // Journal of retailing and consumer services. 2001. - N 8. - P. 157-173.

1. Shenoy, S.S., Sequeira, A. H., \& Devaraj, K. (2012). Service Quality: The Cornerstone of Customer-Centric Retail Strategy for Supermarket Retailers in India. ssrn.com. Retrieved from https://ssrn.com/abstract=2025463. 
2. Cristaller, W. (1996). Centeral Places in Southern Germany, englewood Cliffs. NJ: Prentice-Hall.

3. Kobets V.M. (2009). Tariff policy of transport company-monopolist at delivery of products of $m$ producers to $n$ markets. Actual Problems of Economics, 5, 263-271.

4. Matos, N., Sierra, C., \& Jennings, N.R. (1998). Determining Successful Negotiation Strategies: An Evolutionary Approach. Proc. Third Int'l Conf. Multi-Agent Systems (pp. 182-189).

5. Waterlander, W.E., de Haas, W.E., van Amstel, I., Schuit, A.J., Twisk, J.W., Visser, M., Seidell, J.C., \& Steenhuis, I.H. (2010). Energy density, energy costs and income-how are they related? Public health nutrition, 13(10), 1599-1608.

6. Gunasekaran, A., Lai, Kee-hung, Edwin Cheng, T.C. (2008). Responsive supply chain: Acompetitive strategy in a networked economy. Omega 36, 549-564.

7. Kobets, V., Yatsenko, V., \& Poltoratskiy, M. (2015). Dynamic model of double electronic Vickrey auction. In: Ermolayev, V. et al. (eds.). Proc. 11-th Int. Conf. ICTERI 2015, Kherson, Lviv (pp.236-251). Retrieved from CEUR-WS.org/Vol-1356/ICTERI2015-CEUR-WS-Volume.pdf.

8. Chernikova, H. (2010). Evoliutsiia teorii torhovelnykh tsentriv [The theory evolution of malls]. Tovary $i$ rynky - Products and markets, 2, 27-38. Retrieved from http://nbuv.gov.ua/UJRN/tovary_2010_2_6 [in Ukrainian].

9. Hanson, S. (1980). Spatial Diversification and Multipurpose Travel: Implications for Choice Theory. Geographical Analysis, 12, 245-257

10. Nevin, J.R., \& Houston, M.J. (1980). Image as a Component of Attraction to Intraurban Shopping Areas. Journal of Retailing, 56, 77-93.

11. Nelson, R.R., \& Winter, S.G. (1982). An Evolutionary Theory of Economic Change. Cambridge, MA: The. Belknap Press of Harvard University Press.

12. Ritzer, G. (2004). The "McDonaldization" of Society. The Journal of American Culture, 6 (1), 100-107.

13. 8 largest grocers in the U.S. (n.d.). pennlive.com. Retrieved from http://www.pennlive.com/midstate/index.ssf/ 2015/06/8_largest_grocers_in_the_us.html.

14. Top 10 UK Retailers by Sales in 2015/2016 (n.d.). retaileconomics.co.uk. Retrieved from http://retaileconomics. co.uk/ top10-retailers.asp.

15. USDA Foreign Agriculyural Service. Global Agricultural Information Network (n.d.). gain.fas.usda.gov. Retrieved from https://gain.fas.usda.gov/Recent\%20GAIN\% 20Publications/Retail\%20Foods_Berlin_Germany_11-22-2016.pdf.

16. Laimer, C.G., \& Laimer, V.R. (2009). Relações de cooperação na perspectiva da visão baseada em recursos [Cooperation relations from the perspective of the resource-based view]. Revista de Administração da Unimep - Journal of Management Unimep, 7(3), 93-110.

17. Gaspar, M.A., Borgato, F., \& Lima, I.C. (2013). Estrategia de atuacao em rede de negocios: Estudo de caso no pequeno varejo de alimentos [Business Networking Strategy: Small Food Retail Case Study]. Revista da Micro e Pequena Empresa Journal of Small and Medium Enterprises, 7(1), 3-16 [in Portugal].

18. Marcon, C., \& Moinet, N. (2001). Estratégia-rede: Ensaio de estratégia [Strategy-Network: Strategy Testing]. Caxias do Sul: Educs [in Portugal].

19. Balestrin, A., \& Vargas, L. M. (2004). A dimensão estratégica das redes horizontais de PMEs: Teorizações e evidencias [The strategic dimension of horizontal SME networks: Theorizations and evidences]. Revista de Administração Contemporânea Journal of Contemporary Management, 8(1), 203-228 [in Portugal].

20. Centenaro, A., \& Laimer, C.G. (2017). Cooperative relationships and competitiveness in supermarket sector. Review of Business Management, São Paulo, 19 (63), 65-81.

21. Lima, D.O., Fo. Maia, F.S., Sproesser, R.L., Moraes, F., \& Moraes, R. (2006). Redes de cooperacao no varejo alimentar de vizinhanca: Percepcoes dos asociados [Cooperative networks in the neighborhood food retail: Members' perceptions]. Gestzo \& Produзzo - Management \& Production, 13(2), 311-324 [in Portugal].

22. Ganguli, S, \& Kumar, V.B. (2008). Drivers of customer satisfaction and loyalty in India retail supermarkets: An exploratory study. ICFAI Business Review, June, 61-66.

23. Vieira, J., Yoshizaki, H., \& Ho, L. (2009). Collaboration intensity in the Brazilian supermarket retail chain. Supply Chain Management, 14(1), 11-21.

24. Balestrin, A., \& Verschoore, J. (2016). Redes de cooperazzo empresarial: Estratŭgias de gestao na nova economía [Business Cooperation Networks: Management Strategies in the New Economy]. Porto Alegre: Bookman [in Portugal].

25. Tomar, T.S. (2016). Entrepreneurship Development and Innovation Management Key Connections. In Grant, K.A., \& Wise S. (Eds.). 4th International Conference on Innovation and Entrepreneurship (pp. 263-271).

26. Huang, T., \& Chunxiong, L. (2017). The Distribution Strategies of Convenience Stores Chain in China from Japan 7-11. Web of Conferences 100, 1-5.

27. Lyengar, S., \& Lepper, M. (2000). When choice is demotivating: Can one desire too much of a good thing? Journal of Personality and Social Psychology 79(6), 995-1006.

28. Chen, Shu-Heng, \& Du, Ye.-Rong (2015). Granularity in Economic Decision Making: An Interdisciplinary Review. Granular computing and decision-making: interactive and iterative approaches (pp. 47-71). DOI: 10.1007/978-3-319-16829-6_3.

29. Kobets, V., \& Weissblut, A. (2016). Nonlinear Dynamic model of a microeconomic system with different reciprocity and expectations types of firms: Stability and bifurcations. CEUR Workshop Proceedings, 1614, 502-517. Retrieved from CEUR- 
В.М. Кобець, В.О. Яценко. Що можуть виявити економічні експерименти щодо еволюційної ефективності стратегій супермаркетів?

WS.org/Vol-1614/ICTERI-2016-CEUR-WSVolume.pdf.

30. Mogilner, C., Rudnick, T., \& lyengar, S. (2008). The mere categorization effect. How the presence of categories increases choosers' perceptions of assorment variety and outcome satisfaction. Journal of Consumer Research, 35 (2).

31. Scheibehenne, B., Greifeneder, R., \& Todd, P. (2010). Can there ever be too many options? A metaanalytic review of choice overload. Journal of Consumer Research, 37(3), 409-425.

32. Kuzmin, O.Ye., Sydorov, Yu.l., \& Kozyk, V.V. (2011). Dosiahnennia i problemy evoliutsiinoi ekonomiky [Ahievements and Problems of Evolutionary Economics]. Lviv: Publishing House of Lviv Polytechnic National University [in Ukrainian].

33. Harris, L., \& Ogbonna, E. (2001). Competitive advantage in UK food retailing sector: past, present and future. Journal of retailing and consumer services, $8,157-173$.

B.M. Кобець, канд. екон. наук, доцент, доцент кафедри економічної теорії, заступник завідувача кафедри інсорматики, програмної інженерії та економічної кібернетики, Херсонський національний університет (м. Херсон, Україна)

B.O. Яценко, студент 1-го року магістратури зі спеціальності міжнародна економіка, Київський національний університет імені Тараса Шевченка (м. Київ, Україна)

Що можуть виявити економічні експерименти щодо еволюційної ефективності стратегій супермаркетів?

у роботі аналізуються різноманітні стратегії супермаркетів (імітації та інновації) за допомогою економічних експериментів, згідно яких продажі та ціни адаптуються до ринкового попиту. Порівняння стратегій супермаркетів дозволило продемонструвати переваги стратегії супермаркетів для імітаторів та новаторів за різних умовах. Запропонований алгоритм конкурентоспроможної моделі супермаркетів з нечітким попитом, може бути використаний як конкурентна стратегія в мікроекономічній системі, в якій широкий спектр різних продуктів / послуг продаються через супермаркети. Було виявлено, що імітаційна стратегія в довгостроковій перспективі демонструє свою прибутковість. В той час як, з невеликою кількістю супермаркетів (двох чи трьох) інноваційна стратегія супермаркетів виявиться більш вигідною. Кількість супермаркетів, кількість кроків і середня ціна продуктів позитивно впливають на прибуток супермаркетів обох типів.

Ключові слова: стратегії супермаркетів, економічний експеримент, стратегія імітації, інноваційна стратегія, адаптивний алгоритм.

В.М. Кобец, канд. экон. наук, доцент, заместитель заведующего кафедрой информатики, программной инженерии и экономической кибернетики, Херсонский государственный университет (г.. Херсон, Украина);

B.A. Яценко, студентка 1-го года магистратуры по специальности международная экономика, Киевский национальный университет имени Тараса Шевченко (Киев, Украина)

Что могут выявить экономические эксперименты про эволюционную эффективность стратегий супермаркетов?

В работе анализируются различные стратегии супермаркетов (имитации и инновации) с помощью экономических экспериментов, согласно которым продажи и иены адаптируются к рыночному спросу. Сравнение стратегий супермаркетов позволило продемонстрировать преимущества стратегии супермаркетов для имитаторов и новаторов при различных условиях. Предложенный алгоритм конкурентоспособной модели супермаркетов с нечетким спросом, может быть использован как конкурентная стратегия в микроэкономической системе, в которой широкий спектр различных продуктов / услуг продаются через супермаркеты. Было выявлено, что имитационная стратегия в долгосрочной перспективе демонстрирует свою прибыльность. В то время как, С небольшим количеством супермаркетов (двух или трех) инновационная стратегия супермаркетов окажется более выгодной. Количество супермаркетов, количество шагов и средняя цена продуктов положительно влияют на прибыль супермаркетов обоих типов.

Ключевые слова: стратегии супермаркетов, экономический эксперимент, стратегия имитации, инновационная стратегия, адаптивный алгоритм.

Отримано 29.06.2017 p. 